\title{
NAJSTARIJE LOKACIJE GRADSKE BOLNICE U RIJECI
}

\author{
THE OLDEST LOCATIONS OF \\ CITY HOSPITAL IN RIJEKA
}

\author{
Nana Palinić ${ }^{*}$
}

SAŽETAK

U članku se opisuju najstarije lokacije i zgrade namijenjene liječenju bolesnika u Rijeci. Prema povijesnim izvorima, prvo poznato mjesto namijenjeno zdravstvenoj zaštiti i liječenju bio je hospital osnovan $u$ I4. stoljeću u Starom gradu, u Ulici sv. Sebastijana u kojoj se nalazila i istoimena crkvica. Ne zna se pouzdano kada se bolnica premješta na novu lokaciju, u kuću nasuprot Zborne crkve, smještenu na istočnom kraju tadašnje Ulice sv. Marije (danas Užarska). Statut Rijeke iz 1530. spominje je pod nazivom Bolnica sv. Marije (Spedale di s. Maria), ali poslije mijenja ime u Bolnica sv. Duha po kapeli koja se nalazila u istom bloku zgrada. Kao i na prethodnoj lokaciji, u sklopu bolnice bilo je i sirotište i ubožnica. Bolnica $i$ sirotinjski zavod u ovoj zgradi djelovali su sve do I822., kada se, inicijativom Općine, premještaju na Brajdu u adaptirani kompleks zgrada nekadašnje tvornice voska. Zgrada nekadašnje bolnice adaptirana je za stambenu namjenu. Krajem Drugoga svjetskog rata stradala je u savezničkom bombardiranju i na njenom je mjestu izgrađena nova zgrada.

Ključne riječi: povijest zdravstvenih ustanova, zdravstvena arhitektura, 15. - 19. stoljeće, Rijeka, Hrvatska

\footnotetext{
Adresa za dopisivanje: Nana Palinić, Građevinski fakultet, Sveučilište u Rijeci, Radmile Matejčić 3, 51000 Rijeka, Hrvatska.

ORCID ID: https://orcid.org/0000-0001-8395-7964.

E-pošta: nana.palinic@gradri.uniri.hr.
} 


\section{UvoD}

O najranijim riječkim bolnicama - zapravo ustanovama namijenjenim brizi o bolesnima i nemoćnima pisalo je do sada više autora. ${ }^{1}$ Arhitektura zgrada u kojima su se nalazile, malo je, međutim, obrađena. Najstarije lokacije poznate su samo načelno, a o nekima postoje i različiti podaci. Zgrade nisu sačuvane, a povijesni izvori - i pisani i grafički, vrlo su šturi, pa cjelovita rekonstrukcija izgleda i karakteristika građevina u doba njihove izvorne namjene nije moguća. Ipak, interpretacijom postojećih izvora, najranija lokacija - u Ulici sv. Sebastijana, može se barem pretpostaviti. Drugu lokaciju, uz

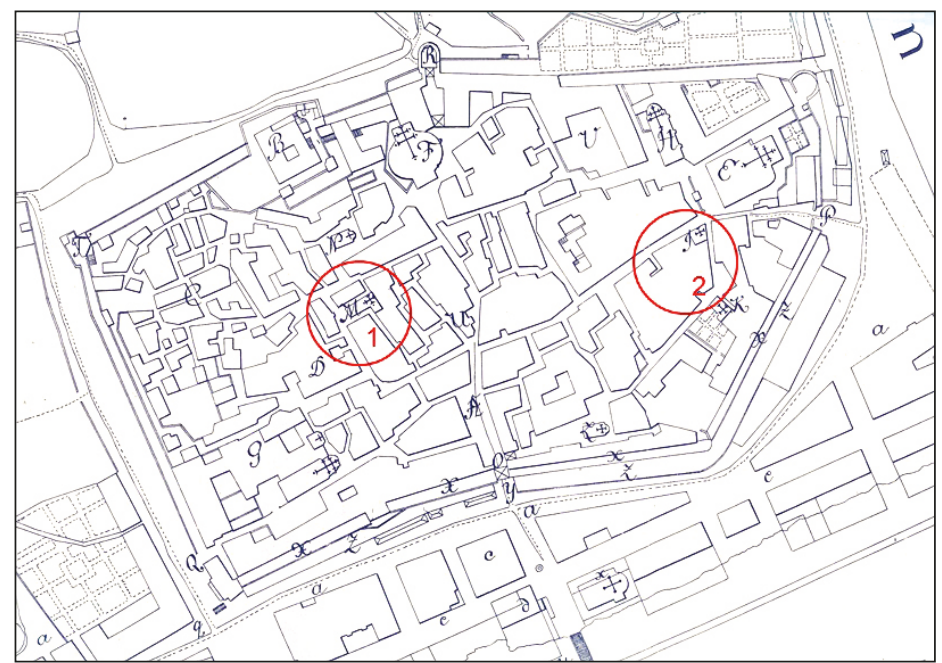

Slika r. Plan Rijeke satnika von B(P)enka iz 1776. - I795.:

I. Lokacija Hospitala u Ul. sv. Sebastijana, 2. Lokacija Bolnice sv. Duha uz Zbornu crkvu

1 Giovanni Kobler i Luigi Maria Torcoletti u okviru širih prikaza riječke povijesti dio posvećuju i gradskoj bolnici. Kobler, Giovanni (1896). Memorie per la storia della liburnica città di Fiume, Rijeka (Fiume); Stabilimento Tipo-litografico Fiumano di Emidio Mohovich, Vol. I, Vol. III; Torcoletti, Luigi Maria (1954). Fiume e i paesi limitrofi, Rapallo; Scuola tipografica s. Girolamo Emiliani. Radmila Matejčić u više članaka, osim povijesnih podataka, daje i podatke vezane uz lokacije i građevine u kojima je djelovala bolnica tijekom povijesti. Matejčić, Radmila; Matejčić, Marijan (1982). Ars Aesculapi - prilozi za povijest zdravstvene kulture Rijeke i Hrvatskog primorja, Rijeka; ICR; Matejčić, Radmila (1989). Kako čitati grad, Rijeka; ICR. Ante Škrobonja analizira karakter ovih ustanova zaključujući kako su u prvom redu socijalne, a tek sekundarno zdravstvene. Stoga se izraz bolnica u naslovu članka treba uzeti samo uvjetno jer su sva mjesta namijenjena skrbi i liječenju bez licenciranoga gradskog liječnika bile karitativne ustanove, odnosno hospiciji. O pravoj bolnici u Rijeci može se govoriti tek nakon 1529., kada se spominje prvi liječnik. Škrobonja, Ante (1984). Socijalno medicinske prilike u Rijeci tijekom 15. i 16. stoljeća. Marko Medved analizira ulogu bratovština u radu prvih hospitala. Medved, Marko (2013), Crtice iz crkvene povijesti Rijeke vezane uz odnos kršćana i zdravstva, Acta Medico-Historica Adriatica, 11(1), 113-130. 
Zbornu crkvu, na kojoj je Gradska bolnica sv. Duha djelovala do početka I9. stoljeća moguće je i precizno odrediti te donijeti i neke zaključke o prostornim i arhitektonskim karakteristikama ove građevine (sl. r.).

\section{Lokacija hospitala uz crkvu Sv. Sebastijana}

Prema povijesnim izvorima, prvo poznato mjesto u Rijeci namijenjeno zdravstvenoj zaštiti i liječenju bio je hospital u Ul. sv. Sebastijana, u kojoj se nalazila i istoimena crkva. Pretpostavlja se da je crkva po kojoj je ulica dobila ime, a koja je posvećena svecu zaštitniku od kuge, sagrađena nakon što je I29I. ova bolest desetkovala Rijeku i Istru. ${ }^{2}$ Točno doba osnivanja hospitala ne zna se. Kobler navodi da se "prvi spomen jedne bolnice u Rijeci nalazi u jednoj javnoj knjizi iz I5. st., gdje se može pročitati u god. I440. da bolnica posjeduje jednu kuću u ulici sv. Sebastijana“. ${ }^{3}$

Kobler ne spominje o kojoj je javnoj knjizi riječ. U Knjizi riječkog kancelara i notara Antuna de Renno de Mutina, koja je glavni izvor za ovo razdoblje, a koju su objelodanili Gigante i Zjačić, u godini I440. nema spomena hospitala ni njegove lokacije, pa primarni izvor ovog podatka ostaje otvoreno pitanje. ${ }^{4}$ Hospital se u ovoj knjizi spominje malo poslije, 1453 ., ali bez naznake lokacije. ${ }^{5}$

Hospital je imao više funkcija, bio je i lazaret, sirotište i ubožnica. Njegova točna lokacija u ulici u kojoj se nalazilo više kuća, nije poznata. ${ }^{6}$ Za bližu lokaciju dragocjen je, međutim, podatak koji navodi Torcoletti, citirajući Poglajena: „Kanonik Poglajen govori kako je u I5. st. postojala u Rijeci mala

2 Kobler navodi da se 1291. kao godina izgradnje navodi u biskupijskim dokumentima. Nakon toga konstatira kako je zacijelo postojala već u prvoj polovici 15. stoljeća. To je neobična konstatacija, koja zapravo dovodi u sumnju raniju dataciju, a bez jasnog obrazloženja. Kobler, G. (1896), Vol. I, 141.

3 Kobler navodi da je hospital osnovan u 15. stoljeću, a Povijest Rijeke u 14. stoljeću. Kobler, G. (1896), Vol. III, 57.; Klen, Danilo, ed. (1988), Povijest Rijeke, Rijeka: Skupština općine Rijeka (SOR), Izdavački centar Rijeka (ICR), 100.

4 Gigante, Silvino (1912) Monumenti di storia Fiumana II, Libri del Cancelliere. Volume primo. Cancelliere Antonio di Francesco de Reno. Parte prima: MCCCXXXVII - MCCCXLIV., Municipio di Fiume, Fiume, 149-202; Gigante, Silvino (1931) Cancelliere Antonio di Francesco de Reno. Parte seconda: Anno X (1445-1457), "Fiume" rivista semestrale della Societa di studi Fiumani in Fiume, Fiume, 108-117; Zjačić, Mirko (1955-1956). Knjiga riječkog kancelara i notara Antuna de Renno de Mutina (1436-1461), Vjesnik Državnog arhiva u Rijeci, svezak III., Rijeka, 32-37.

$5 \quad$,... qualiter emit a regimine dicte Terre Fluminis vnum ortum sicut stat seralea, situm in dicta Terra Fluminis iuxta hospitale, et viam publicam, ...". Zjačić, Mirko (1959) Knjiga riječkog notara i kancelara Antuna de Renno de Mutina (1436-1461) - III. Dio, Vjesnik Historijskog arhiva u Rijeci, svezak V., Rijeka., 443-444.

6 Sredinom 19. stoljeća u Ulici sv. Sebastijana i u njenoj neposrednoj blizini ima oko 30 kuća, ali kućni broj u ulici nosi 18 kuća. 
bolnica u kući pokraj crkvice Sv. Sebastijana i bolesnici su mogli s jednog prozora, koji je gledao iz kuće u crkvu, slušati svetu misu."7 Ova činjenica sužava lokaciju samo na kuće koje su bile u neposrednoj blizini crkve, a isključuje one koje su bile u istoj ulici, ali udaljenije.

Crkva sv. Sebastijana jednobrodna je građevina pravokutnog tlocrta, $\mathrm{s}$ ulazom na zapadnom pročelju te sa po tri prozora na sjevernom i južnom, dok je istočno pročelje slijepo. Tijekom vremena nekoliko je puta obnavljana. $\mathrm{O}$ njenom izgledu u doba izgradnje, kao ni u I4. i I5. stoljeću nema podataka. Memorijalni natpis nad vratima označava godinu obnove koju je bratovština na čelu s Ivanom Dotićem poduzela i562., kada vjerojatno u njenoj blizini više nije bio hospital. ${ }^{8}$

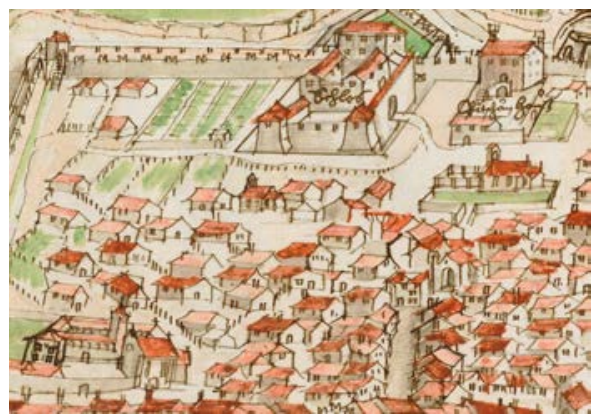

Slika 2. Rijeka 1578., Ivan Klobučarić, detalj

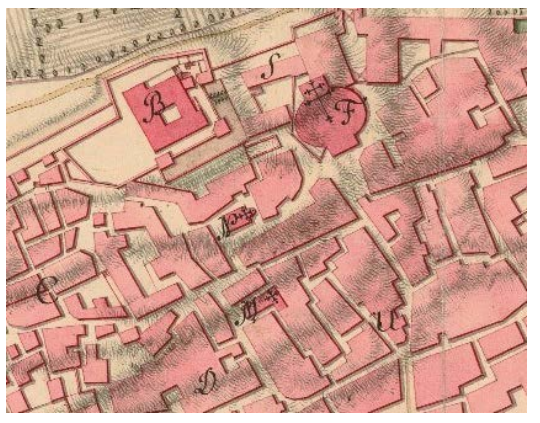

Slika 3. Rijeka 1776., Von B(P)enko, detalj

Najraniji grafički prikazi grada nastali su u i6. stoljeću. Grad prikazuju iz ptičje perspektive i nedovoljno su precizni da se iz njih može nešto više zaključiti o izgledu crkve i lokaciji hospitala. Na najranijem prikazu grada iz 1550. te grafici iz I67I. crkva je ucrtana kao samostojeća građevina sa zvonikom, jednako kao i sve ostale crkve u gradu, pa je očito da je prikaz sakralnih građevina samo simboličan, ne i realan. ${ }^{9} \mathrm{Na}$ prikazu iz 1578 . Ivana

Torcoletti, M. L. (1954), 34. Torcoletti ne navodi bibliografsku referencu, a u jedinom objavljenom radu Poglajena, Memorie cronologiche relative alle chiese e al capitolo di Fiume (Fiume, 8 (1930.) 1-2, 106-180) taj podatak nije naveden, što nije neobično. Ovaj je rad zapravo izbor iz rukopisnih spisa kanonika Poglajena sačuvanih u župnom arhivu Zborne crkve, koje je sakupio i objavio Silvino Gigante, navodeći da su neki od tih spisa od relativne važnosti, te se ovdje ograničava na objavljivanje onih koje mu se čine najzanimljivijima za našu javnu i privatnu povijest. Torcoletti je, s obzirom na to da su mu originalni Poglajenovi spisi morali biti dostupni, podatak vjerojatno pronašao u dijelu spisa koji Gigante nije izdvojio i objavio.

8 Kobler, G. (1896), 141-142.

9 Fivme, autor Giorgio Genova. Ekl, Vanda (1989). Fluminensia, Rijeka; SOR, ICR, Pomorski i povijesni muzej Hrvatskog primorja Rijeka (PPMHPR), 6. 
Klobučarića (sl. 2.) ispod Kaštela ucrtana je crkva sa zvonikom na preslicu i apsidom, ali vjerojatno je riječ o crkvici sv. Mihovila, a ne sv. Sebastijana, na što upućuje detalj apside. Crkva sv. Sebastijana na ovom, inače prilično realističnom prikazu Rijeke, nije posebno označena, što je neobično s obzirom na to da je poznato kako je njeno značenje bilo veće od sv. Mihovila. Moguće je da je Klobučarić nije posebno istaknuo zbog toga što u to doba nije bila samostojeća građevina, već spojena s drugim zgradama. Plan satnika von $\mathrm{B}(\mathrm{P})$ enka iz $\mathbf{1 7 7 6}$. (sl. 3.) prvi precizno prikazuje gradske ulice i blokove. ${ }^{10} \mathrm{Na}$ planu je vidljiva gusta izgradnja ovog dijela Staroga grada. Crkva sv. Sebastijana uklopljena je u veći izduljeni blok zgrada koji se proteže s njene istočne strane, a u neposrednoj blizini sa sjeverne, zapadne i južne strane postoji izgradnja. Crkva nema pravokutan oblik, već oblik obrnutog slova L - glavni pravokutni gabarit u jugoistočnom dijelu ima manju dogradnju.

Najraniji plan koji prikazuje parcelaciju Starog grada, tj. na kojem su ucrtane pojedinačne kuće je onaj Ignazija Rossija iz I842. ${ }^{11}$ (sl. 4.). Po gabaritima blokova uglavnom je podudaran $\mathrm{s}$ prethodnim planom. ${ }^{12}$ Iz njega je vidljivo da se u neposrednom susjedstvu crkve nalazi devet zgrada. Zapadno nasuprot ulazu ucrtane su tri kuće u nizu, pod brojevima I25, I26 i ı27, južno od crkve je kuća pod brojem I36, sjeverno od crkve su dvije spojene kuće pod brojevima I43 i 144 te kuća I45, a istočno kuće I46 i I47. Ako se misa mogla pratiti preko

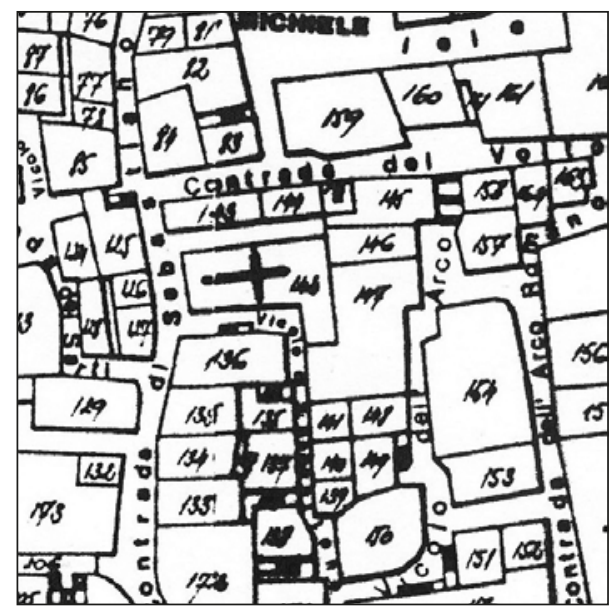

Slika 4. Crkva sv. Sebastijana i susjedne kuće na detalju Katastarskog plana Ignazzija Rossija iz i842. (precrt koji je 1993. izradio Ivan Šupraha) vanjskog prozora hospitala, taj se prozor mogao nalaziti samo na poziciji kuća koje se nalaze sa strane ulaza ili pročelja s prozorima, tj. u nizu nasuprot ulazu

10 Plan des in Littorali austriaco ligender Freien Mer-porto und Stadt Fiume. HR-DARI 57 (JU 51), kut. 106; Ekl, Vanda (1994), 170-171;

11 HR-DARI Državni arhiv u Rijeci, Kartografska zbirka, Ignatius Rossi, 1842. Precrt plana izradio je 1993. Ivan Šupraha, a za objavu u ovom radu ustupila Olga Magaš, na čemu joj zahvaljujem.

12 Ne podudara se u samo jednom detalju - prolazu između kuća na sjevernoj strani, koji na ranijem planu postoji. 
(I25-I27), na kućama sjeverno (I43, I44, I45) ili kući na južnoj strani (I36).13 Praćenje mise bilo bi moguće samo uz otvorena vrata, odnosno prozore crkve, ograničeno na dane kada to vremenski uvjeti omogućavaju.

U gruntovnim knjigama koje prate ovaj plan za kuće pod ovim brojevima zapisano je sljedeće: Crkva sv. Sebastijana bila je na br. I42 (stari 390 i 395 te drevni 234/232), ${ }^{14}$ od čega se stari broj 390 odnosi na glavni prostor crkve, a 395 na sakristiju. Površina je iznosila $4 \mathrm{I} \mathrm{kv}$. hvata $\left(\mathrm{I} 47,6 \mathrm{~m}^{2}\right),{ }^{15}$ od toga 35 brod $\left(\mathrm{I} 26 \mathrm{~m}^{2}\right)$ i $6\left(2 \mathrm{I}, 6 \mathrm{~m}^{2}\right)$ sakristija. Kuća na br. I25 (stari 373, drevni 287/290) bila je u vlasništvu Catterine Baretich r. Bernardini (prije kapetana Giovannija Bernardinija) i imala prizemlje, 3 kata i tavan. Površina je bila oko 8 kv. hvata (oko $66 \mathrm{~m}^{2}$ ). Kuća na br. 126 (stari 374, drevni 286/289) bila je u vlasništvu Catterine Scaglia i Terese Sandrini i imala prizemlje, I. kat i tavan. Površina je bila $7 \mathrm{kv}$. hvati i $3 \mathrm{kv}$. stope $\left(25,64 \mathrm{~m}^{2}\right)$. Kuća na br. I27 (stari 375 , drevni 285/288) bila je u vlasništvu Lucije Maser r. Cergnaz, a sastojala se od podruma i r. kata. Imala je površinu od I4 kv. hvati i $2,5 \mathrm{kv}$. stope (oko $5 \mathrm{I} \mathrm{m}^{2}$ ).

Kuća na br. ${ }_{3} 6$ (stari 384, drevni 274/277) bila je u vlasništvu Natalea Matejcicha i Antonija Michicha i imala prizemlje, dva kata i tavan. Površina je bila od 2I kv. hvata i $4 \mathrm{kv}$. stope $\left(\right.$ oko $\left.76 \mathrm{~m}^{2}\right)$.

Kuća na br. I43 (stari 39I, drevni 239/237) bila je u vlasništvu Giovannija Squase i imala je prizemlje i dva kata. Površina je bila 2 I kv. hvat i 3,5 kv. stope (oko 77,5 m²). Kuća na br. I44 (stari 392, drevni 238/236) bila je u vlasništvu Marije Reppach r. Michich (prije Giuseppea Michicha) i imala je prizemlje, tri kata i tavan te površinu od II kv. hvati (oko 39,6 m²). Kuća na br. I45 (stari 393, drevni 237/235) bila je u vlasništvu (vinara?) supružnika Giuseppea i Marije Blecich (prije nasljednika Tudorovich) i imala prizemlje i dva kata te dvorište s bunarom. Površina je bila 32 kv. hvati, 2 kv. stope, 4 kv. palca (oko II6 $\mathrm{m}^{2}$ ). Ova je kuća najveća od svih koje su okruživale crkvu, a nisu na nju bile naslonjene. Jedina je koja ima i bunar, što je svakako povoljno za funkciju hospitala. Ipak, iz te kuće, koja je samo jednim uskim dijelom bila u blizini crkve, teško bi se mogla pratiti misa.

13 Adresu Ul. sv. Sebastijana, osim same crkvice imaju, međutim, samo kuće nasuprot ulazu, dok su ostale bile orijentirane na susjedne ulice (sjeverne na Contrada del Volto, a južna na Vicolo di st. Sebastiano).

14 Drevni broj uz stari 390 nije upisan. Državni arhiv u Rijeci (HR-DARI), Fond Zemljišno knjižni odjel Rijeka (PR-18), knjiga 20.

15 Bečki hvat (Klafter Wiener) sastoji se od 6 stopa i iznosi 189,66 cm, a u upotrebi je do 1875 . Jedan kvadratni hvat iznosi oko $3,6 \mathrm{~m}^{2}$. Jedna stopa sastoji se od 12 palaca i iznosi $31,61 \mathrm{~cm}$, a kvadratna stopa oko $0,1 \mathrm{~m}^{2}$. Jedan palac iznosi oko $2,63 \mathrm{~cm}$, a kvadratni palac oko 0,0007 $\mathrm{m}^{2}$. Herkov, Zlatko (1971). Mjere Hrvatskog primorja, Rijeka; Historijski arhiv u Rijeci i Pazinu, Posebna izdanja svezak 4, 108. 
S obzirom na to da su stari i drevni brojevi svih kuća koje su okruživale crkvu bili različiti, može se zaključiti kako su od davnina sve kuće izgrađene kao samostalni objekti i nisu nastale naknadnim pregrađivanjem neke veće kuće. Većina je kuća bila vrlo skučena - najveća je zajedno s dvorištem imala II6 $\mathrm{m}^{2}$, što je vjerojatno premalo za sadržaj kakav je hospital. Ako se misa, međutim, pratila iz unutarnjeg prozora hospitala, onda se taj prozor mogao nalaziti samo u kućama koje su bile naslonjene na crkvu - br. I46 ili ı 47. U ovom slučaju bolesnici bi bili u mogućnosti pratiti misu tijekom cijele godine, bez obzira na vremenske uvjete.

Kuća na br. 146 (stari 394, drevni 232/230) dijelila je s crkvom pola istočnog pročeljnog zida (oko $2,9 \mathrm{~m}$ ). Imala je površinu od $15 \mathrm{kv}$. hvati, $3 \mathrm{kv}$. stope i $4 \mathrm{kv}$. palca (oko 54,4 m²). I ova kuća je vrlo male površine, nedovoljne za smještaj hospitala. Kuća koja je s crkvom dijelila dva zajednička zida - pola istočnog zida broda crkve te cijeli istočni i dio južnog zida sakristije (ukupno oko Iз m) je kuća na br. 147 (stari 395, drevni 233/23I i 234/232). Imala je površinu od 55 kv. hvati i $5 \mathrm{kv}$. stopa $\left(199,2 \mathrm{~m}^{2}\right)$. Iz gruntovnih brojeva može se zaključiti da je kuća nastala spajanjem dvije - manje od $\mathrm{I5} \mathrm{kv}$. hvati i $4 \mathrm{kv}$. stope (drevni broj 233/23I) i veće od $40 \mathrm{kv}$. hvati i I kv. stope (drevni broj 234/232). Bila je razvedenog tlocrta - modificiranog slova $S$ te imala prizemlje, tri kata i tavan koji je dijelom bio stambeni. U prizemlju su u to doba dva podruma i jedno skladište, a na katovima stanovi. Na prvom katu, koji je bio u ravnini crkve, bile su soba i kuhinja orijentirane na zapadnu stranu te jedna dvorana (sala). Na drugom katu bile su soba, kuhinja i hodnik te još jedna soba i kuhinja na zapadnoj strani. Na trećem katu bile su soba i kuhinja te još jedna sobica s kuhinjom, a na četvrtom (tavanu) dvije sobe. Unutar kuće bila su i dva stubišta te spremište žita. Do i824. kuća je bila u vlasništvu Giuseppea Dinaricha, a od te godine Santa Ianellija. Od I835. kuća ima više vlasnika, čiji se udjeli kreću od I6/30 (Santo Ianelli, od I846. Giuseppe Petricich), II/30 (Apolonia ud. Ratkovich koju r840. nasljeđuju Catterina Ianelli i Carolina De Ronchi), 2/30 (Margareta Margan) i I/30 (Nicolo Matejcich - naslijedio ga je Natale Matejcich).

Ovo je ujedno najveća kuća u blizini crkve. Ono što ih dodatno povezuje jesu stari i drevni brojevi sakristije, koji su isti (395 i 234/232), što znači da je sakristija nekad bila sastavni dio ove kuće, a naknadno je postala dio crkve. Tlocrt crkve (sl. 5.) to potvrđuje - između crkve i sakristije postojao je velik otvor, gotovo u cijeloj širini sakristije. ${ }^{16}$ Ako se hospital nalazio na mjestu

16 HR-DARI, JU 51, kut. 85, br. 9/3. 
kuće br. I47, nakon njegova premještanja na drugu lokaciju (vjerojatno u i6. stoljeću) zgrada je promijenila namjenu u stambenu. Budući da je bila relativno velika, s vremenom je podijeljena između više vlasnika. Nakon premještanja hospitala, prostor koji je služio kao komunikacija između crkve i hospitala bio bi najpogodniji da se na njega proširi crkva te da se pretvori u sakristiju.

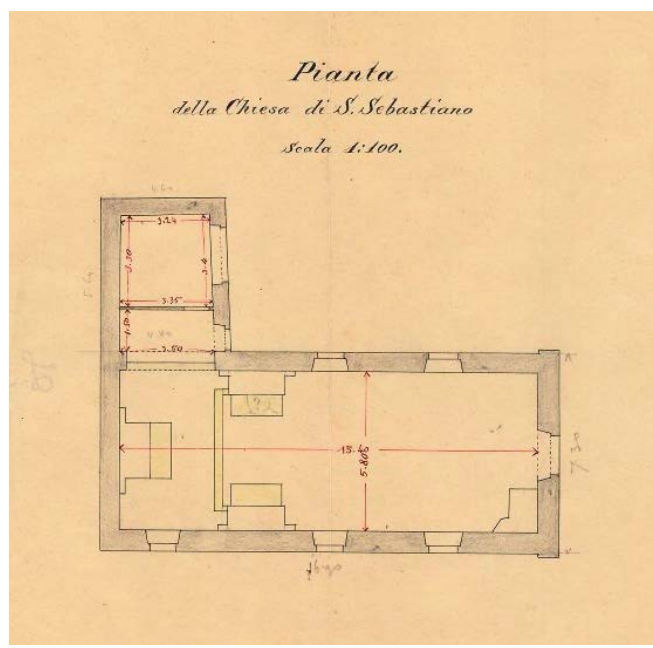

Slika 5. Tlocrt crkve sv. Sebastijana, i884., G. Paulinovich (HR-DARI)

Ostaje otvoreno pitanje kada se to moglo dogoditi te možemo li godinu 1562. , kada je crkva obnovljena, ili r642., koja je zapisana na kamenu ugrađenom u južno pročelje crkve, povezati s tim događajem ili s nekadašnjim hospitalom.

O crkvi se brinula Bratovština sv. Sebastijana (s promjenom titulara poslije sv. Fabijana i Sebastijana). Bratovština je, zajedno s većinom drugih, ukinuta 1787. i iste godine crkva je zatvorena te je bilo određeno njeno rušenje. Vjernici su ovo spriječili i crkva se ponovno otvara 179I., a I806. se i obnavlja. Još jedan pokušaj rušenja, u svrhu oslobađanja prolaza prema kućama smještenim odostraga, bio je i833., ali ni taj nije ostvaren. Crkva je obnavljana i r885., kada je u klasicističkom duhu restaurirano pročelje prema projektu arhitekta G. Paulinovicha. ${ }^{17}$

Što se događalo sa susjednom zgradom br. I47 možemo dijelom rekonstruirati prateći plansku dokumentaciju. Na planu grada iz i859. dopunjena je ili promijenjena numeracija kuća. ${ }^{18}$ Crkva sv. Sebastijana sada ima br. I48, 
a kuća br. 447 podijeljena je na dva dijela granicom koja je nastavak istočnog zida crkve i sakristije. ${ }^{19}$ Istočni je dio kuće veći, a zapadni manji, ali nose isti broj I47/I40. Na katastarskom planu grada iz I86I. podjela kuće je ista, ali je numeracija promijenjena, veći istočni dio kuće sada nosi br. 469, manji 470, a crkva ima br. $436 .{ }^{20} \mathrm{Na}$ planu iz 1876 . situacija je nepromijenjena, ali plan nema numeracije. Ni na planu iz I889. nema promjena. ${ }^{21}$ Budući da su prikazani ulični brojevi kuća vidimo da je crkva na adresi Via san Sebastiano 8, zapadni dio kuće I47 na adresi Vicolo san Sebastiano 8, a istočni na adresi Vicolo dell' Arco Romano 7.

Na planovima koje su 1934. sačinili arhitekti Gradskoga građevnog ureda Giovanni Carboni i Guido Lado tijekom izrade prijedloga regulacijskog plana vidljivo je da je istočni dio kuće podijeljen na dvije kuće, obje orijentirane na Calle dei Ronchi. Crkva ima novi broj, 286/I, a sakristija 286/2. Zapadni dio kuće I47 više ne postoji, dok dvije kuće na istočnoj strani br. I47 imaju brojeve 273/r i 273/2. Premda su regulacijskim planom mnoge kuće u Starom gradu bile predviđene za rušenje, to se nije dogodilo i s ovim kućama koje su očito bile u građevinski i arhitektonski solidnom stanju. U poslijeratnom

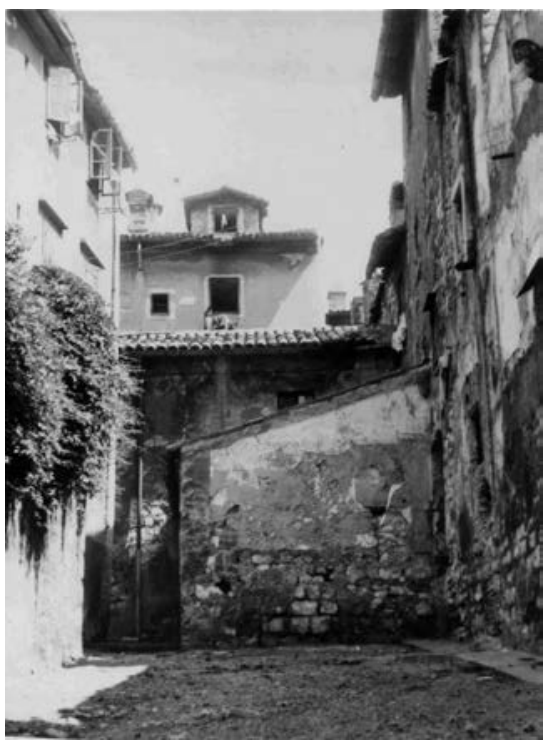

Slika 7. Pogled na južno pročelje crkve sv. Sebastijana i sakristiju te zapadno pročelje kuće br. I47

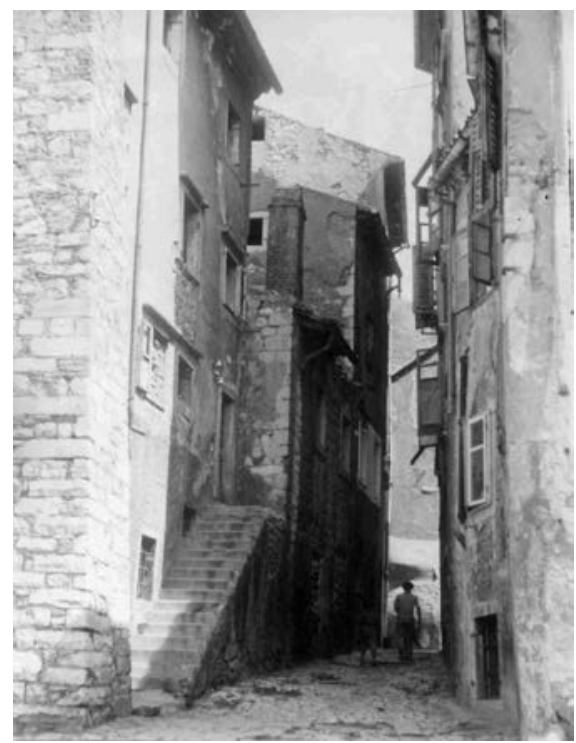

Slika 8. Pogled na kuće br. I49, I48 i I47, I954. (Šerak, Konzervatorski odjel MK u Rijeci, Fototeka)

19 Zid o kojemu je riječ podignut je na mjestu zapadnog obodnog zida antičkog Principija.

20 HR-DARI, Kartografska zbirka.

$21 \quad$ V. bilješku 17. 
razdoblju istočni dio kuće, prethodno podijeljen na dva dijela, nosi br. 9 i II u Ul. Balde Lupetine. Obje će kuće biti srušene između 1954. i $1955 .{ }^{22}$ Prije rušenja, 1954. ove kuće snimio je fotograf Konzervatorskog ureda Ministarstva kulture Šerak (sl. 6., 7. i 8.), što, zbog nedostatka drugih izvora, ostaje jedini dokument o njihovu izgledu. Sakristija crkve, nekad dio kuće I47, bila je jednostavna građevina pokrivena jednostrešnim krovom. Na zapadnom pročelju bio je prozor te za četiri stube $(60-80 \mathrm{~cm})$ podignuta ulazna vrata. ${ }^{23}$ Jednostavan kameni okvir obrubljuje otvor vrata. ${ }^{24} \mathrm{U}$ drugom planu vidljiv je dio zapadnog pročelja kuće $\mathbf{1 4 7}$, a fragment pročelja vidljiv je i na drugoj fotografiji (sl. 7.). Većina otvora prizemlja jednostavnog je pravokutnog oblika, pojedini imaju kamene okvire, a neki i natprozornike pokrivene redom crijepova. U prizemlju, neposredno uz južni zid sakristije, veći je otvor segmentnog završetka (možda vrata) te jedan potpuno kružni otvor. Ispod oštećene žbuke vidljiva je kamena struktura zida, izvedena od krupnijega poluobrađenog kamena složenog u relativno pravilne redove, a kod kružnog otvora vidljiva je (antička?) opeka.

Cijelo je područje godinama stajalo neizgrađeno, da bi nakon provedenih arheoloških istraživanja 20I4. na tome mjestu bili prezentirani arheološki ostaci nekadašnjega antičkog Principija - vojnog zapovjedništva iz 3. - 4. stoljeća. Usporedimo li prezentirane ostatke Principija s povijesnim planovima, možemo zaključiti da su zgrade koje se od srednjeg vijeka podižu u ovoj zoni, uključujući crkvu sv. Sebastijana i zgradu I47, nastale na temeljima ove antičke građevine. Arheološka istraživanja potvrdila su autentičnost antičkih zidova u zoni ispod razine crkve sv. Sebastijana, odnosno u prizemnoj zoni kuća koje su bile s njene istočne strane - kuće I45, I46, I47. Istočni dio kuće I47 izgrađen je nad dvije južne od četiri pomoćne prostorije zapadnog krila Principija, te nad dijelom Principija koji se nalazi južno od ovih prostorija, a čiji je pod izvorno bio na nešto nižoj razini. Zapadni dio kuće izgrađen je na otprilike etažu višoj razini. Nosivi zidovi Principija iskorišteni su i nadograđeni te se i nakon izgradnje ovih kuća na planovima grada mogao razaznati pravilan obris nekadašnje antičke građevine. Najranije postantičke građevine nastaju na mjestima na kojima je bilo iskoristivoga građevinskog materijala - obrađenog kamena i opeke, te gdje su već postojale nosive strukture koje

22 Na planu iz 1952. još su sačuvane, a na planu iz 1955. nisu (prikazane su crtkano, kao i svi drugi objekti koji su u međuvremenu srušeni).

23 Prozor je ucrtan u tlocrtu iz 1884., ali nije vidljiv na fotografijama.

24 Na pomoći oko identifikacije sakristije zahvaljujem konzervatoru dr. sc. Željku Bistroviću, a na pomoći u istraživanju fotografu Damiru Krizmaniću, iz Konzervatorskog odjela Ministarstva kulture u Rijeci. 
su se mogle iskoristiti. Stoga se može pretpostaviti da su upravo građevine podignute na nosivim zidovima Principija ujedno i najstarije, što, uz crkvu sv. Sebastijana, uključuje i zgradu I47 koja vjerojatno nije puno mlađa od crkve, a možda nastaje i u isto vrijeme. Upravo na mjestu ove kuće pronađeno je najviše nalaza iz razdoblja srednjeg vijeka i renesanse - kasnosrednjovjekovna otpadna jama koja je korištena dulje razdoblje, kao i novac i keramički nalazi iz 15 . stoljeća. ${ }^{25}$ Je li hospital bio prva funkcija zgrade ili je to nastao adaptacijom (bilo na ovoj ili nekoj drugoj lokaciji), ostaje otvoreno pitanje.

\section{LOKACIJA BOLNICE UZ ZBORNU CRKVU}

Ne zna se kada se bolnica premješta s lokacije pored sv. Sebastijana u kuću nasuprot Zborne crkve (Uznesenja BD Marije), koja se nalazila na istočnom kraju Ulice sv. Marije (danas Užarska). U Statutu Rijeke iz 1530. spominje se hospital sv. Marije ${ }^{26}$ pa je logično pretpostaviti da je ime bolnice vezano uz novu lokaciju, naziv ulice i obližnje crkve. ${ }^{27}$ Manje je vjerojatno, ali ne i posve isključeno, da je bolnica još na prijašnjoj lokaciji dobila ime sv. Marije, posebno ako je u njenim aktivnostima još tada sudjelovala bratovština tog imena. ${ }^{28}$ Ostalo je zabilježeno da je 1567 . nadvojvoda Karlo, tijekom posjeta Rijeci, obećao materijalnu pomoć gradskom skloništu bolesnih, siromašnih i nemoćnih. ${ }^{29}$ Nekoliko godina poslije, 1572 ., gradska uprava određuje daće u korist bolnice. Nadvojvoda Karlo patentom potvrđuje ovu odluku, a bolnici daruje i crkvicu sv. Marije na Škurinjama, zajedno s njenim posjedima. ${ }^{30} \mathrm{Ne}$ zna se ni kada je bolnica - prema kapeli koja se nalazila u istoj zgradi, promijenila ime u Bolnica sv. Duha. Vrijeme gradnje kapele također nije poznato,

25 O tome detaljnije u: Višnjić, Josip (2009). Ostaci srednjovjekovne i novovjekovne arhitekture na Trgu Jurja Klovića; Bekić, Luka (2009). Numizmatički nalazi kasnog srednjeg vijeka, novog vijeka i modernog doba; Čimin, Robert (2009). Kasnosrednjovjekovni, novovjekovni i moderni keramički nalazi, u: Radić Štivić, Nikolina; Bekić, Luka ed., Tarsatički principij, Rijeka: Grad Rijeka, Hrvatski restauratorski zavod. 2009, 299-376.

26 "...et in quoliet casu supradicto vendens sive faciens panem minus pensa, cujus medietas deveniat officialibus inventoribus et alia medietas hospitali Sanctae Mariae.” Kobler i Gigante "hospitalis/hospitale" prevode kao bolnica (ospedale), dok Herkov prevodi kao ubožnica. Kobler (1896), Vol. III., 57.; Herkov, Zlatko; Gigante, Silvino (2001). Statutum Terrae Fluminis, Rijeka; Edit - ICR, 350-351.

27 U korist ove teze govori i podatak koji navodi Torcoletti, kako je bolnica ,imala i jednu kapelicu posvećenu isprva Madoni, a kasnije sv. Duhu“. Torcoletti, M. L. (1954), 34.

28 U Knjizi riječkoga gradskog notara Antonia de Rena navodi se kako je 1454. odlučeno da uprava Bratovštine sv. Marije preuzme skrb nad dobrima svih bratovština, osim sv. Ivana. Kobler, G. (1896), Vol. I, 154. Viezzoli također navodi da je Bolnica sv. Marije bila pored crkve sv. Sebastijana. Viezzoli, Giuseppe (1932), Contributi alla storia di Fiume nel Settecento, Fiume Rivista semestrale, I e II 1932., 161.

29 Klen, D., ed., (1988), 131.

30 Kobler, G. (1896), Vol. III, 58. 
ali se pretpostavlja da je to moralo biti u i6. stoljeću, kada je zabilježeno da se u kapeli slavilo bogoslužje, a 1632. biskup Giulio Sozomeno je posvetio novi oltar. ${ }^{31}$ O lokaciji i zgradi same bolnice malo je do sada objelodanjenih podataka. Kobler navodi da je „postojala mala bolnica, pod imenom sv. Duha na trgu pred Zbornom crkvom na uglu gdje se susreću duga ulica i ona koja vodi do bivšeg Millerovog trga“"32 te kako se kapela sv. Duha nalazila na samom uglu zgrade. ${ }^{33}$ Podatak, dijelom izmijenjen, prenosi Matejčić te navodi da se „bolnica nalazila na uglu Trga sveta Tri Kralja i Ulice svete Marije“. ${ }^{34}$ Objavljuje i ilustraciju s naznačenom približnom lokacijom, uz potpis: „Rijeka u XVII st. Označen Trg sv. Tri Kralja gdje je bila prva bolnica sv. Duha“. ${ }^{35}$ Riječ je o očitoj pogrešci, s obzirom na to da kao izvor navodi Koblera, koji je naznačio točnu lokaciju. U drugom članku to i ispravlja te navodi: „Na uglu Ulice sv. Tri Kralja i te kontrade (sv. Marije, nap. a.) nalazila se kuća k.br. 290 u kojoj je bio smješten riječki Hospital Sv. Duha zajedno s Ubožnicom.“"36

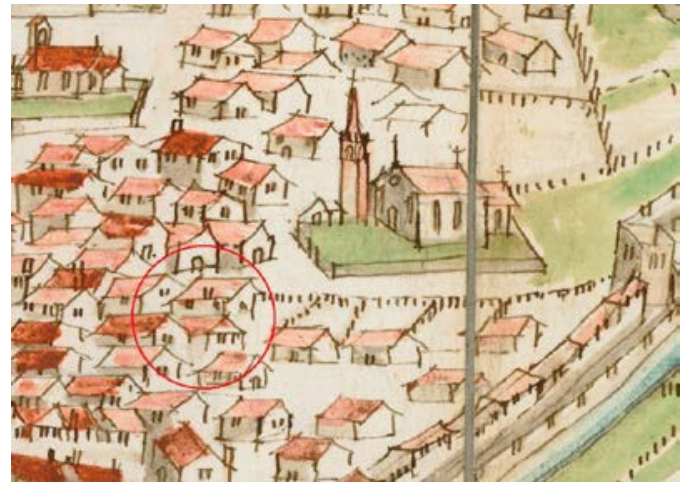

Slika 9. Rijeka 1578., Ivan Klobučarić, detalj

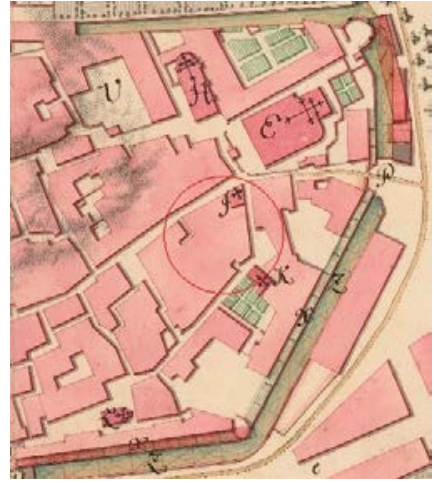

Slika Io. Rijeka I776., Von B(P)enko, detalj

Iz prikaza grada iz I6. stoljeća, poput Klobučarićeva (sl. 9.), ne može se dobiti više podataka o lokaciji kapele sv. Duha ni bolnice. Ispred Zborne

Kobler, G. (1896), Vol. I., 148.

32 Izvorno Piazzetta del Duomo doslovno bi značilo Katedralni trg, međutim riječka Zborna crkva nije bila katedrala, niti su je u hrvatskom jeziku tako nazivali, te je naveden naziv trga koji je bio uobičajen.

33 Kobler, G. (1896), Vol. III, 58.

34 Matejčić, R., Matejčić, M. (1982), 136.; prethodno objavljeno u: Acta historica medicinae pharmaciae veterinae, 1971.

35 Matejčić, R., Matejčić, M. (1982), 134. Ista ilustracija s krivo označenom lokacijom objavljena je i u monografiji: Đirlić, Anđelko, ed., (2009), Klinički bolnički centar Rijeka 1984. 2009., Rijeka: KBC Rijeka.

36 Matejčić, R. (1989), 174.; prethodno objavljeno u: Naša Rijeka, 1984. 
crkve, na navedenom mjestu prikazana je nešto veća samostojeća kuća dvostrešnog krova, koja se bitno ne razlikuje od susjednih. U Jozefinskom katastru iz $1785 .-1787$. pod br. 268 (36) upisana je Bolnica s dvorištem. ${ }^{37}$ S obzirom na susjedne lokalitete očito je riječ o bolnici uz Zbornu crkvu. ${ }^{38}$ Nema planova koji prate Jozefinski katastar, a iz ovog razdoblja sačuvani su samo planovi satnika von $\mathrm{B}(\mathrm{P})$ enka od $\mathrm{I} 776$. do I795. (sl. ıo.) na kojima je vidljivo da se kapela sv. Duha nalazila na samome sjeveroistočnom uglu

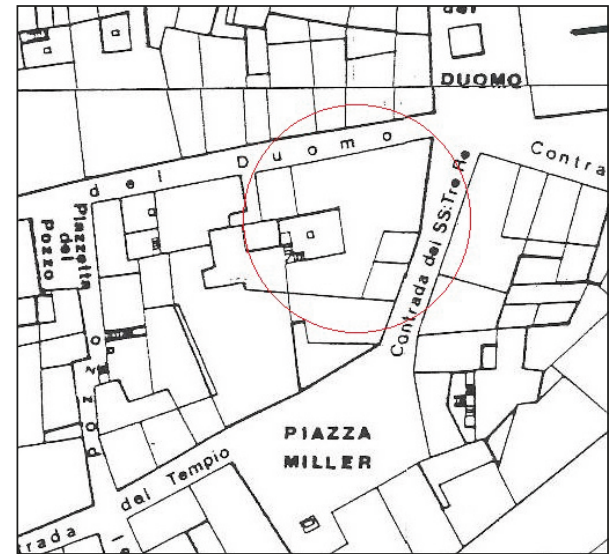

Slika ir. Zgrada Bolnice sv. Duha na detalju Katastarskog plana Ignazzija Rossija iz I842. (precrt koji je 1993. izradio Ivan Šupraha) većeg bloka zgrada, omeđenom ulicama. Sigurnu potvrdu lokacije bolnice donosi plan I. Rossija iz I842. ${ }^{39}$ (sl. Ir.).

Zgrada o kojoj je riječ ima broj 295 i nalazi se na sjeveroistočnom dijelu bloka omeđenog Ulicom Zborne crkve (Via del Duomo) sa sjevera, Ulicom i trgom bunara (Contrada del Pozzo i Piazzetta del Pozzo) sa zapada, Ulicom Hrama (Contrada del Tempio) i Trgom Tri kralja (Piazza tre Re) s juga i Uličicom Tri kralja (Vicolo del Tre Re) s istoka. Dva ulična pročelja, dulje sjeverno i kraće istočno spajala su se pod oštrim uglom na samom trgu pred Zbornom crkvom. Na planu je vidljivo i četvrtasto dvorište s bunarom. U zemljišnim knjigama koje prate ovaj plan na broju 295 (stari I25, drevni 67/66) ${ }^{40}$ upisan je komentar: „Prethodno u vlasništvu Javnog magistrata Rijeke i u upotrebi stare građanske bolnice sv. Duha, nakon toga prelazi u vlasništvo Giuseppea Ielleticha (Jeletića) i Ant. (Antonia) Pascoletta temeljem ugovora koji je s njima sklopljen u gradskom Magistratu 30. travnja I824. ${ }^{\text {(41 }}$

\footnotetext{
37 „Špital nebst hoff“. Erceg, Ivan (1998), Jozefinski katastar grada Rijeke i njegove uže okolice (1785/87), Zagreb; Školska knjiga, 52.

38 Tekstualni dio katastra ne prate odgovarajući planovi pa za neke zgrade nije moguće odrediti točnu lokaciju, već samo približnu.

39 V. bilješku 10.

40 Niti jedan od navedenih brojeva ne podudara se s brojevima iz Jozefinskog katastra, ali ni s brojevima poznatih planova na kojima postoji numeracija kuća.

41 HR-DARI, PR-18, knjiga 21.
} 
O bolnici i njenom unutarnjem izgledu u povijesnim izvorima gotovo da nema podataka. Kobler navodi da je bolnica bila malena, ${ }^{42}$ a Torcoletti procjenjuje da nije mogla imati više od pola tuceta kreveta. ${ }^{43}$ Dokument iz 1712. navodi podatak vezan uz dvorište bolnice. Dvije godine prije, I7io., napravljen je popis nekretnina - njih ukupno 24, koje je bolnica u to doba posjedovala. Bila je riječ o većim i manjim kućama, stanovima, skladištima i podrumima u gradu te vinogradima izvan grada, čija je ukupna vrijednost bila 556o, odnosno I230 dukata. ${ }^{44}$ Nekretnine su bile u najmu, ali su prihodi od najma bili mali, ukupno 749 dukata godišnje. ${ }^{45}$ Stoga je 1712. donesena odluka da se sve nekretnine prodaju, a da se zadrže samo kućice „izgrađene u dvorištu bolnice koje su služile za smještaj udovica i siročadi““ ${ }^{46}$ Većina nekretnina je očito prodana jer Jozefinski katastar iz i785. - 1787. u vlasništvu bolnice navodi na području Rijeke još samo dvije nekretnine, u sjeverozapadnom dijelu Staroga grada, u predjelu Gomila. ${ }^{47}$

O veličini zgrade u kojoj se nalazila bolnica, približnom broju i rasporedu postorija najviše se zaključaka može donijeti iz zemljišnih knjiga koje prate plan iz I842. Kuća je nakon prodaje bila podijeljena u jednakim dijelovima na svakog od vlasnika. Giuseppe Ieletich posjedovao je 30/60 (tj. 1/2) nekretnine i imao u vlasništvu prvi kat, pola tavana prema sjeveru i tri skladišta u prizemlju prema Contrada del Duomo. Antonio Pascoletto imao je u vlasništu

42 Kobler, G. (1896), Vol. III, 58.

43 Torcoletti, M. L. (1954), 34.

44 Bolnica je 1712. posjedovala deset većih i šest manjih kuća, tri stana, tri skladišta i dva podruma. Posjedovala je: kuću koju drži Zuane (Zvane) Zazan (?) od 700 dukata, kuću s dva podruma koje drži ud. Craglich od 500 dukata, kuću koju drži Mattio Susanich od 400 dukata i kuću koju drži ud. Ferutti (?) od 400 dukata, kuću koju drži g. Colona od 400 dukata, kuću koju drži ud. Francetich od 300 dukata, kuću koju drži Schenderich od 300 dukata, kuću koju drži Sebastiano Maltarese od 300 dukata, kuću koju drži Mistro Valincich od 300 dukata, kuću koju drži (baron?) Giacomo Cavina od 250 dukata, kućicu koju drži Blas Schittar od 200 dukata, kuću koju drži Giovanna ud. Dudi, r. Bontich od 150 dukata, kućicu (Casino) koju nastanjuje Georgio Milos, susjednu koju drži ud. Grassich od 150 dukata, kućicu koju drže ud. Mulaf i Maglienaf od 150 dukata, kućicu koju drži Bartolo Radoncich od 100 dukata, stan koji drži Anton Fortunatich od 150 dukata, stan koji drži Ivan co. Conacich od 150 dukata, kuhinju i sobicu koje drži gosp. Vluin (?) od 120 dukata, skladište koje drži (baron?) Scherbich od 120 dukata, skladište koje drži gosp. Lorenzo Stemberg(er) od 280 dukata, skladište koje drži g. Africh od 200 dukata, podrum koji drži Gasparo Cocenar od 100 dukata, podrum koji drži ud. Marg. Barcich od 120 dukata. HRDARI, JU 2, Verb. Cap. 21.01.1712. Popis je, ali parcijalan i s greškama, objavio Viezzoli u: Viezzoli, G. (1932), 162.

45 Kobler navodi lire a Viezzoli dukate.

46 Viezzoli, G. (1932), 161-162.

47 Na br. 504 (317) bolnica je posjedovala jednu kuću, a na br. 537. (36) vrt, vinograd i pašnjak. Površina kuće nije navedena, a za parcelu se navodi površina od 1 brava $\left(\right.$ oko $\left.255 \mathrm{~m}^{2}\right)$, tj. 14 i $1 / 6$ hvati u duljinu i 5 u širinu $(26,9 \times 9,48 \mathrm{~m})$. 
drugi kat, pola tavana prema jugu te dvije trgovine, skladište i dva podruma u prizemlju prema dvorištu.

Antonio Pascoletto umro je 17. srpnja 1839. i nakon toga njegov je dio kuće podijeljen između četiri nasljednika. Giorgio Pascoletto dobio je ro/6o nekretnine i imao u vlasništvu dvije sobe, kuhinju i ostavu na drugom katu prema zapadu, kao i pola tavana prema jugu s dozvolom gradnje. ${ }^{48}$ Pietro Pascoletto dobio je $7 / 60$ nekretnine i imao u vlasništvu tri sobe, kuhinju sa sobom služavke prema istoku na drugom katu te jedan podrum u prizemlju orijentiran prema dvorištu. Lorenza Pessi rođ. Pascoletto dobila je 7/60 nekretnine i imala u vlasništvu tri sobe, kuhinju sa sobom služavke prema sjeveru na drugom katu te jedan podrum u prizemlju orijentiran prema dvorištu. ${ }^{49}$ Pasqualina Pascoletto dobila je 6/60 nekretnine i imala u vlasništu dvije trgovine i jedno skladište orijentirano prema dvorištu.

Iz navedenog se može zaključiti od kojih se prostorija zgrada bivše bolnice sastojala petnaest godina nakon iseljenja bolnice. U prizemlju su se s uličnih strana nalazila tri skladišta (prema Contrada del Duomo) i dvije trgovine (orijentacija nije jasno naznačena), a prema dvorištu skladište i dva podruma. $\mathrm{Na}$ drugom katu su bila tri stana - jedan orijentiran na zapad, koji se sastojao od dvije sobe, kuhinje i ostave, drugi orijentiran na istok, koji se sastojao od tri sobe, kuhinje i sobe služavke, te treći, orijentiran na sjever, koji se sastojao od tri sobe, kuhinje i sobe služavke. Može se zaključiti da je i prvi kat bio slično organiziran, odnosno sastojao se od približno istog broja prostorija. Uz ove prostore, na jednom i drugom katu moralo je biti i ostalih prostora namijenjenih komunikaciji (hodnici, degažmani) i higijeni (zahodi). Tavan je bio podijeljen na sjeverni i južni dio i u ono doba vjerojatno nije služio stanovanju.

Ukupna korisna površina zgrade iznosila je oko $290 \mathrm{kv}$. hvati, odnosno oko Io $48 \mathrm{~m}^{2}$, tj. oko $262 \mathrm{~m}^{2}$ po etaži. Dvorište je bilo malo, od oko $120 \mathrm{~m}^{2}$, blago trapeznog, gotovo pravokutnog oblika. U središnjem dijelu bio je bunar, a u jugozapadnom uglu dvokrako stubište L-tlocrta koje je vodilo na gornje etaže južnog krila. S obzirom na to da su svi prizemni prostori s dvorišnim pristupom bili u vlasništvu obitelji Pascoletto, u zemljišnim je knjigama stavljena

48 Giorgio Pascoletto umro je 16. ožujka 1846., ali u zemljišnim knjgama nije upisan nasljednik. HR-DARI, PR 18, knjiga 21.

49 Lorenza Pessi 17. srpnja1839. naslijedila je i manju kuću s brojem 293, koja se nalazila zapadno od spomenutog dvorišta, a koja je prethodno bila u zajedničkom vlasništvu Antonija Pascoletta i Giuseppea Ielleticha (ovdje navedenog kao Gieletich). Kuća je imala prizemlje i dva kata i vlasnica je imala pravo pristupa dvorištu i bunaru kuće na br. 295. HR-DARI, PR-18, knjiga 21. 


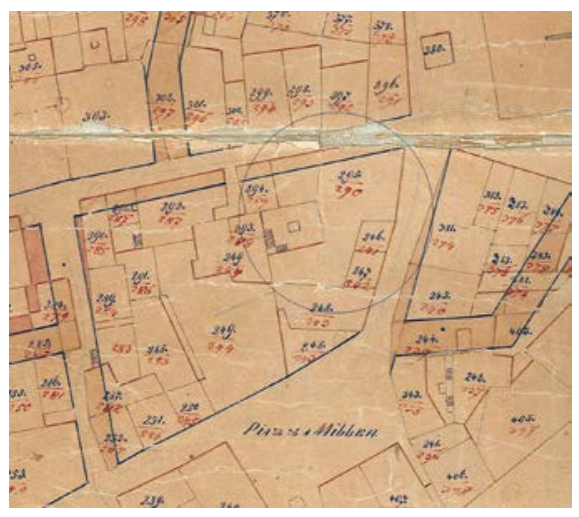

Slika I2. Rijeka r859., detalj

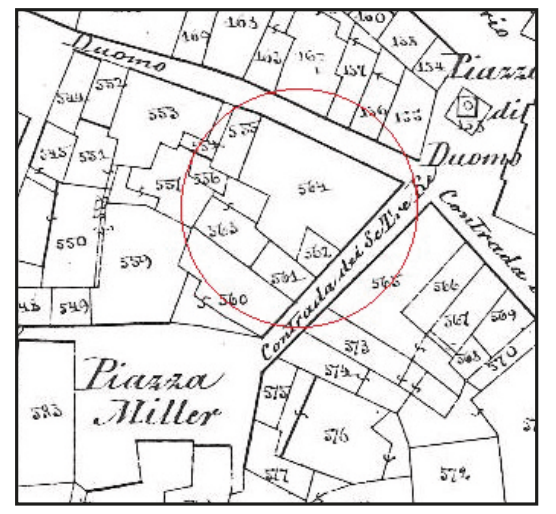

Slika I3. Rijeka I86r., detalj

bilješka kako G. Ielletich, vlasnik druge polovice zgrade, ima pravo korištenja bunara u dvorištu, pravo na isto dvorište, pravo ulaza i prolaza stubištem koje vodi na prvi i drugi kat te na tavan, pravo korištenja zajedničkog prostora na trećem katu (tavanu) te pravo na zajednički prostor u prizemlju. $\mathrm{Na}$ najranijim planovima na kojima je prikazana parcelacija blokova - iz I842. (sl.

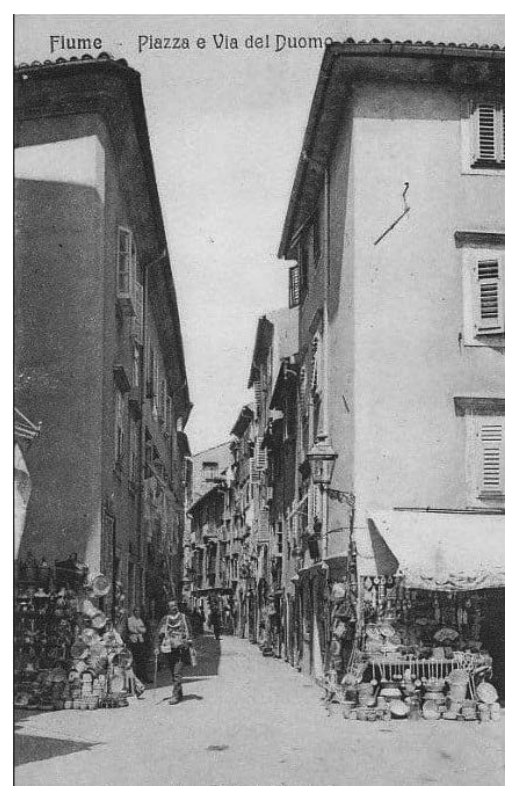

Slika I4. Pogled na Užarsku ulicu (Via del Duomo) i zgradu u kojoj se nekad nalazila Bolnica sv. Duha (lijevo)
Ir.) i r859. (sl. I2.) vidljivo je da je tlocrt bolnice bio nepravilnog U-oblika i da je imala sjeverno, istočno i južno krilo, što je moguća posljedica kasnijih dogradnji ili spajanja više zgrada. Na kasnijim planovima, primjerice iz 186r. (sl. I3.) zgrada je podijeljena na dva dijela - veći T-gabarita koji ima br. 564 i manji četvrtasti br. $563 .{ }^{50} \mathrm{Krajem}$ I9. i početkom 20. stoljeća zgrada je imala tri etaže: prizemlje i dva kata, što je vidljivo i na jedinoj sačuvanoj fotografiji s prijelaza stoljeća (sl. 14.). Iz fotografije se može razaznati devet prozorskih osi na pročelju koje gleda prema Via del Duomo, pravokutni otvori lokala u prizemlju s okvirima od kamena, pravokutni prozori katova s klasicističkim minimalno profiliranim natprozornicima. Djelomičnu rekonstrukciju unutarnjeg rasporeda

50 HR-DARI, Kartografska zbirka. 


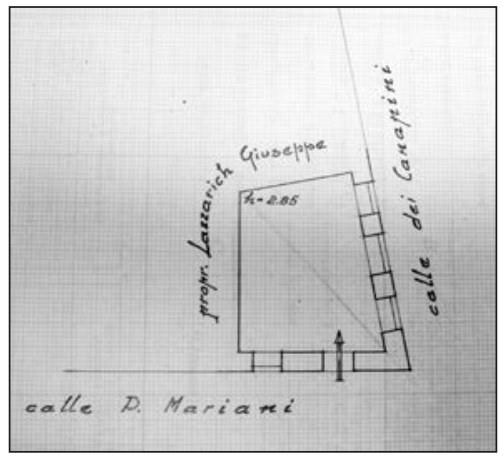

Slika 15 . Tlocrt trgovine na mjestu nekadašnje kapele sv. Duh

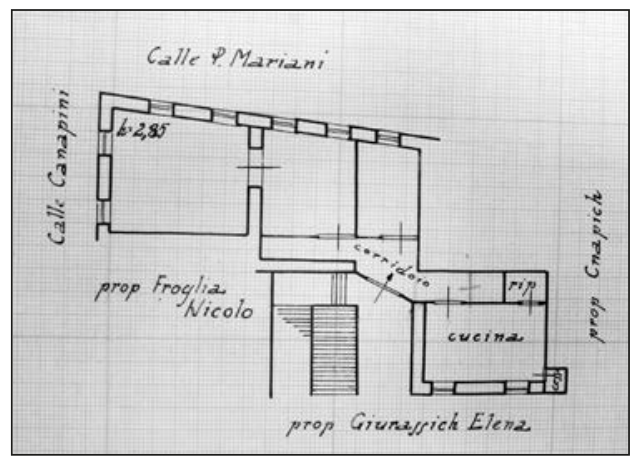

Slika i6. Tlocrt ugaonog stana nad kapelom na I. katu, I938.

prostorija moguće je sačiniti iz još kasnijih dokumenata. Unutar upisnih lista zgrade iz I939. sačuvane su snimke nekih njenih dijelova - lokala i stanova. ${ }^{51}$ Premda su snimke rađene u mjerilu, nisu u potpunosti točne jer su vjerojatno ovisile o preciznosti referenta koji ih je radio. Tlocrt ugaone trgovine ne odstupa od geodetske izmjere te vjerojatno precizno ilustrira prostor u kojem se izvorno nalazila kapela sv. Duha - trapezoidnog tlocrta, s tri otvora prema sjeveru i dva prema istoku te svijetlom visinom od 2,85m (sl. 15.). U nekoliko stoljeća promijenio se ulaz, koji u ovo doba više nije bio na sjevernoj strani. Skice stanova na gornjim etažama znatno su nepreciznije (sl. I6.). Ipak, može se zaključiti da je zgrada na sjevernom pročelju na gornjim katovima imala po devet prozora, a na istočnom po pet. Tri stana, koji odgovaraju opisu iz zemljišnih knjiga iz I842., locirana su unutar T-gabarita zgrade (br. 564 iz I86r.) i samo je ovaj dio zgrade imao punu katnost. Južno krilo orijentirano na dvorište (br. 563) imalo je prizemlje i kat. Raspored glavnih zidova, položaj glavnih prostorija i stubišta vjerojatno su bili isti i u doba kad su u zgradi bili smješteni bolnica i sirotinjski zavod. ${ }^{52}$ Moguće je da je u prvo vrijeme zgrada bila manja, te da je poslije - vjerojatno u drugoj polovici I8. stoljeća nadograđena. ${ }^{53}$ Osim obodnih nosivih zidova, još je jedan nosivi zid bio u središtu zgrade. Ulaz je po svemu sudeći bio iz Ulice sv. Tri kralja, do prvog kata vodilo je dvokrako stubište U-tlocrta, a na gornjim etažama stubište L-tlocrta nejednakih krakova. Na prvom i drugom katu vjerojatno su se nalazile glavne prostorije za liječenje i njegu. Bilo ih je dvadesetak, uglavnom orijentiranih

1 HR-DARI, JU 51, 3.3., kut. 287.

52 Bolnica i Sirotinjski zavod bili su institucionalno odvojeni do 1786. kad se ujedinjuju u jednu ustanovu. Viezzoli, G. (1932), 164.

53 Matejčić navodi kako su zgrade u ovom dijelu Starog grada uglavnom izgrađene nakon velikog potresa iz 1750. g., međutim zgrada je postojala i ranije, ali je moguće da je nakon potresa nadograđena. Matejčić, R. (1989), 175. 
na ulice, dok su pomoćni prostori - njih desetak bili orijentirani na dvorište. S obzirom na stalno zaposleno osoblje, u zgradi su morali biti i drugi prostori nužni za funkcioniranje: portirnica, kuhinja, blagovaonica, praonica, spremišta hrane i ogrjeva, mrtvačnica. Na koji je način prostor bio podijeljen između bolnice i zavoda, ne zna se. Moguće da je južno dvorišno krilo zgrade pripadalo Sirotinjskom zavodu i da je riječ o nekadašnjim kućicama za smještaj udovica i siročadi, koje se spominju I7I2., ali vjerojatno je zavod koristio znatan dio zgrade. U drugoj polovici 18 . stoljeća u zgradi je bilo smješteno 50 do 60 ljudi - zaposlenika, bolesnika, siromaha i siročadi. Zabilježeno je da je 1794. bilo I7 siromaha, I5 siročadi i Ig bolesnika, a zavod se brinuo i o stotinjak drugih siromaha. ${ }^{54}$ Početkom I9. stoljeća bilo je sedam do osam stalno zaposlenih. ${ }^{55}$ Kako je grad rastao, rastao je i broj štićenika - r821. skrbili su O 30 siromaha i 24 siročića. ${ }^{56}$ Iste godine kupljena je zgrada bivše voštarnice Cavalli i Licudi na Brajdi, u kojoj će bolnica i zavod započeti s radom I823. ${ }^{57}$

Zgrada bivše Bolnice sv. Duha stradala je u savezničkom bombardiranju krajem Drugoga svjetskog rata, a njene ruševine stajale su još nekoliko godina. Na slici Romola Venuccija iz I95ı. (sl. 17.) vidljive su ruševine sjeverozapadnog ugla kuće i južnog krila. Na fo-

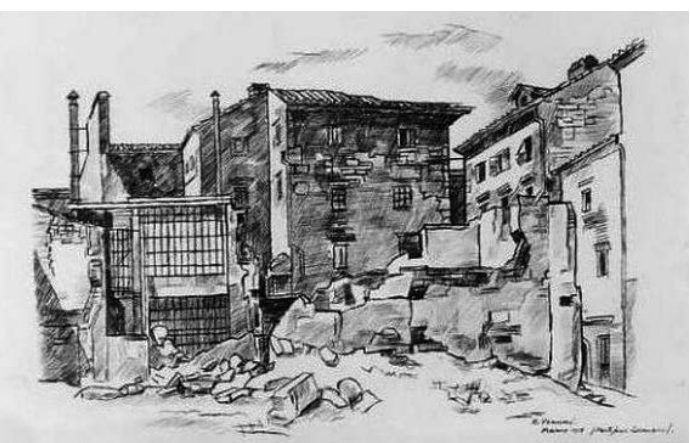

Slika 17. Ruševine kuće u kojoj se nekad nalazila bolnica na slici Romola Venuccija, I95I. tografiji iz 1954. (sl. I8.) vidi se da je dio ruševina uklonjen, a na njihovu je mjestu podignuta armiranobetonska ograda. Sljedeće godine, prema projektu arhitekta Josipa Petraka, na mjestu ruševina uređen je parkić i dječje igralište, za što je iskorišten materijal srušene kuće. ${ }^{58}$ Godine 1983 . prema projektu arhitekta Vladimira Grubešića na ovom je mjestu izgrađena nova zgrada Jadrošpeda. ${ }^{59}$

54 Viezzoli, G. (1932), 164.

55 Godine 1810. u bolnici su bili zaposleni administrator, pomoćni administrator, liječnik, kirurg, kapelan, dvije primalje i šest slugu (čuvara). Godine 1818. među zaposlenima bili su administrator, liječnik, kirurg, portir, dvije medicinske sestre, kuharica i služavka. Kobler, G. (1896), Vol. III, 60, 61.

56 Isto, 61 .

57 Isto, 62.

58 Matejčić, R. (1989), 174.

59 Magaš, Olga (1998), Prilog konzervatorskoj dokumentaciji - objekti izgrađeni nakon 1945. g., Provedbeni urbanistički plan Stari Grad, Rijeka: Grad Rijeka. 


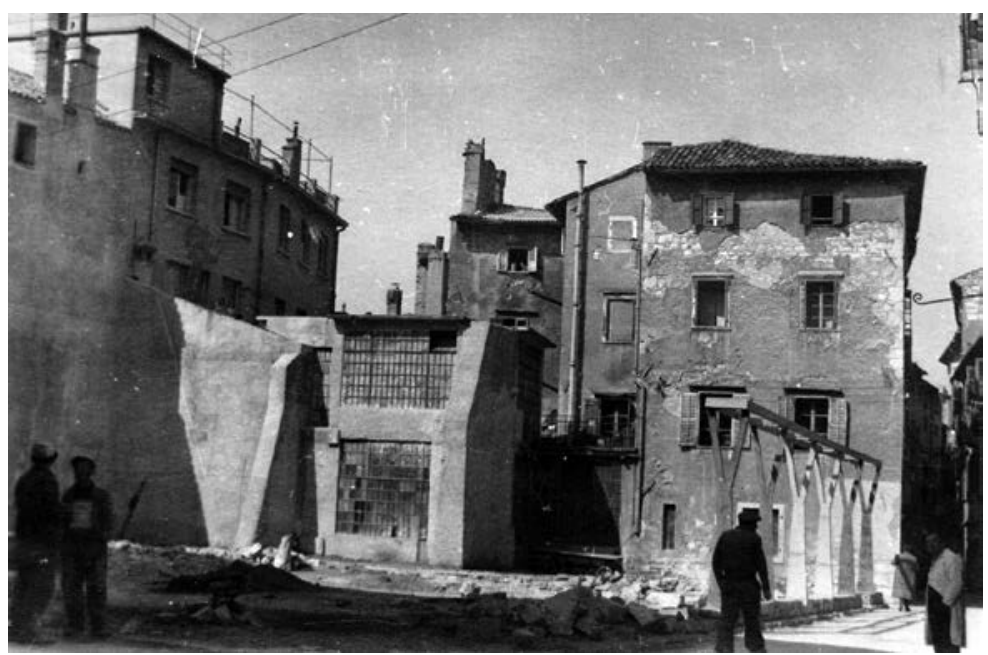

Slika ı8. Pogled na lokaciju na kojoj se nekad nalazila bolnica na uglu Užarske i Marijanske ul.

(Šerak, I954., Konzervatorski odjel MK Rijeka, Fototeka)

\section{ZAKLJUČAK}

Najranije lokacije riječkih hospitala - u kojima se od srednjeg vijeka skrbilo o bolesnima i nemoćnima, načelno su poznate. Precizne lokacije, koje su se ovim radom nastojale utvrditi, uglavnom nisu bile u fokusu znanstvenog istraživanja. Izvora za istraživanje, kako primarnih tako i sekundarnih, iznimno je malo, ali se i iz njih, ako su točni, mogu izvesti neki novi zaključci. Tijekom povijesti medicina i religija bile su čvrsto povezane pa ne začuđuje što su i dvije najstarije lokacije riječkih hospitala bile u blizini sakralnih građevina - crkvice sv. Sebastijana, Zborne crkve i kapele sv. Duha. Kuća koja je bila naslonjena na crkvicu sv. Sebastijana, ujedno i najveća kuća u neposrednoj blizini, naizglednija je prva lokacija. Prostrana kuća koja se nalazila na trgu nasuprot Zborne crkve sigurno je i potvrđeno mjesto na kojem je sve do I822. bila smještena prva prava riječka bolnica, uz koju se nalazio i sirotinjski zavod. I dalje ostaje mnogo pitanja vezanih uz prostornu i funkcionalnu organizaciju ovih ustanova na koje se za sada ne može dati odgovor, a za što će biti nužni neki novi izvori i nova istraživanja. ${ }^{60}$

60 Osim dvaju hospitala čije su lokacije predmet članka, postojao je i treći, dosad nepoznati hospital augustinaca pustinjaka u zapadnom predgrađu grada, na Andrejšćici. Prve podatke o ovom hospitalu objelodanio je Marko Medved u članku objavljenom nakon izrade ovog rukopisa. Točna lokacija hospitala za sada nije poznata i nužno će biti predmet nekih novih istraživanja. Medved, Marko, (2019), Nepoznati hospital Augustinaca pustinjaka riječkog sv. Jeronima. Prilog povijesti medicine u Rijeci, Acta medico-historica Adriatica, 17(2); 195 212. Buduća istraživanja crkvenih redova (na primjer pavlina koji su posjedovali gostinjac) i bratovština koje su djelovale u Rijeci mogla bi također donijeti nove podatke o ovoj temi. 


\section{IZVORI I LITERATURA}

1. HR-DARI 22 (JU 2) Državni arhiv u Rijeci, Fond Općina Rijeka, Verb. Cap. 21.01.1712.

2. HR-DARI (PR 18) Državni arhiv u Rijeci, Zemljišno knjižni ured Rijeka, knj. 20, 21.

3. HR-DARI Državni arhiv u Rijeci, Kartografska zbirka, Ignatius Rossi, 1842.

4. HR-DARI 57 (JU 51) Državni arhiv u Rijeci, Tehnički uredi grada Rijeke, kut. 85 , br. $9 / 3$.

5. HR-DARI 57 (JU 51), Državni arhiv u Rijeci, Tehnički uredi grada Rijeke, kut. 106.

6. HR-DARI 57 (JU 51), Državni arhiv u Rijeci, Tehnički uredi grada Rijeke, kut. 287.

7. Bekić, Luka (2009). Numizmatički nalazi kasnog srednjeg vijeka, novog vijeka i modernog doba; u: Radić Štivić, Nikolina; Bekić, Luka ed., Tarsatički principij, Rijeka: Grad Rijeka, Hrvatski restauratorski zavod. 2009, 299-376.

8. Čimin, Robert (2009). Kasnosrednjovjekovni, novovjekovni i moderni keramički nalazi, u: Radić Štivić, Nikolina; Bekić, Luka ed., Tarsatički principij, Rijeka: Grad Rijeka, Hrvatski restauratorski zavod. 2009, 299-376.

9. Ekl, Vanda (1989). Fluminensia, Rijeka; Skupština općine Rijeka, Izdavački centar Rijeka, Pomorski i povijesni muzej Hrvatskog primorja Rijeka.

10. Ekl, Vanda (1994), Živa baština, Izdavački centar Rijeka, Rijeka.

11. Erceg, Ivan (1998), Jozefinski katastar grada Rijeke i njegove uže okolice (1785/87), Zagreb; Školska knjiga, 52.

12. Gigante, Silvino (1912), Monumenti di storia Fiumana II, Libri del Cancelliere. Volume primo. Cancelliere Antonio di Francesco de Reno. Parte prima: MCCCXXXVII - MCCCXLIV., Municipio di Fiume, Fiume, 149-202.

13. Gigante, Silvino (1931), Cancelliere Antonio di Francesco de Reno. Parte seconda: Anno X (1445-1457), "Fiume" rivista semestrale della Societa di studi Fiumani in Fiume, Fiume, 108-117.

14. Herkov, Zlatko (1971). Mjere Hrvatskog primorja, Rijeka; Historijski arhiv u Rijeci i Pazinu, Posebna izdanja svezak 4, 108.

15. Herkov, Zlatko; Gigante, Silvino (2001). Statutum Terrae Fluminis, Rijeka; Edit ICR, 350-351.

16. Klen, Danilo, ed., (1988), Povijest Rijeke, Rijeka: Skupština općine Rijeka i Izdavački centar Rijeka (ICR), 100.

17. Kobler, Giovanni (1896). Memorie per la storia della liburnica città di Fiume, Rijeka (Fiume); Stabilimento Tipo-litografico Fiumano di Emidio Mohovich, Vol. I, Vol. III. 
18. Magaš, Olga (1998), Prilog konzervatorskoj dokumentaciji - objekti izgrađeni nakon 1945. g., Provedbeni urbanistički plan Stari Grad, Rijeka: Grad Rijeka.

19. Matejčić, Radmila; Matejčić, Marijan (1982). Ars Aesculapi - prilozi za povijest zdravstvene kulture Rijeke i Hrvatskog primorja, Rijeka; ICR.

20. Matejčić, Radmila (1989). Kako čitati grad, Rijeka; ICR.

21. Medved, Marko (2013), Crtice iz crkvene povijesti Rijeke vezane uz odnos kršćana i zdravstva, Acta medico-historica Adriatica, 11(1), 113-130.

22. Medved, Marko (2019), Nepoznati hospital Augustinaca pustinjaka riječkog sv. Jeronima. Prilog povijesti medicine u Rijeci, Acta medico-historica Adriatica, 17(2), 195-212.

23. Poglajen, Giuseppe (1930), Memorie cronologiche relative alle chiese e al capitolo di Fiume (Gigante, Silvino, ed.), Fiume, 8 1-2, 106-180.

24. Škrobonja, Ante (1984). Socijalno medicinske prilike u Rijeci tijekom 15. i 16. stoljeća, Magistarski rad, Rijeka; Medicinski fakultet Sveučilišta u Rijeci.

25. Torcoletti, Luigi Maria (1954). Fiume e i paesi limitrof, Rapallo; Scuola tipografica s. Girolamo Emiliani.

26. Viezzoli, Giuseppe (1932), Contributi alla storia di Fiume nel Settecento, Fiume Rivista semestrale, I e II, 161.

27. Višnjić, Josip (2009). Ostaci srednjovjekovne i novovjekovne arhitekture na Trgu Jurja Klovića; in: Radić Štivić, Nikolina; Bekić, Luka ed., Tarsatički principij, Rijeka: Grad Rijeka, Hrvatski restauratorski zavod. 2009, 299-376.

28. Zjačić, Mirko (1955-1956.), Knjiga riječkog kancelara i notara Antuna de Renno de Mutina (1436-1461), Vjesnik Državnog arhiva u Rijeci, svezak III., Rijeka, 32-37.

29. Zjačić, Mirko (1959), Knjiga riječkog notara i kancelara Antuna de Renno de Mutina (1436-1461) - III. Dio, Vjesnik Historijskog arhiva u Rijeci, svezak V., Rijeka, 443-444. 


\section{SUMMARY}

The article describes the oldest locations and buildings for the treatment of patients in Rijeka. According to historical sources, the first known site for health care and treatment was a hospital founded in the I4th or I5th century in the Old Town, in the St Sebastian Street, in which also existed a little church of the same name. It is not known for sure when the hospital was moved to a new location, to a house opposite the Church of the Assumption of the Blessed Virgin Mary. The Statute of Rijeka from 1530 mentions it under the name Hospital of St. Mary (hospitali Sanctae Mariae) but later changed its name to St. Spirit Hospital. It was named after the chapel located in the same block of buildings. As in the previous location, there was an orphanage and an almshouse within the hospital. The hospital and the orphanage operated in this building until 1822 , when, at the initiative of the Municipality, they moved to Brajda, in an adapted complex of buildings of the former wax factory. The building of the former hospital has been adapted for residential use. At the end of World War II, the building was destroyed under aerial bombardment and later a new building was built in its place.

Keywords: History of health institutions; Medical architecture, XV-XIX Century; Rijeka, Croatia 